\title{
MENANAMKAN NILAI AGAMA PADA ANAK USIA DINI DI KELUARGA ARAB
}

\author{
Nafisah Mufidah ${ }^{1}$; Nurfadilah $^{1}$ \\ ${ }^{1}$ Program Studi Pendidikan Guru Pendidikan Anak Usia Dini, Fakultas Psikologi dan Pendidikan, \\ Universitas Al Azhar Indonesia, Jalan Sisingamangaraja Kebayoran baru, Jakarta Selatan 12110 \\ Penulis untuk Korespondensi/ E-mail: nurfadilah@uai.ac.id
}

\begin{abstract}
Abstrak - Metode adalah suatu cara atau jalan yang harus dilalui untuk mencapai tujuan tertentu. Bagaimana orang tua menjalankan peran juga dapat dipengaruhi oleh faktor budaya. Orang tua akan mengikuti bagaimana pengasuhan yang diterapkan oleh budayanya. Metode penelitian yang digunakan adalah penelitian kualitatif dengan pendekatan kualitatif deskriptif. Data yang diperoleh dari 6 orang tua dan 3 anak menggunakan teknik wawancara dan observasi. Kemudian data tersebut dianalisis menggunakan metode Miles dan Huberman yang meliputi pengumpulan data, reduksi data, penyajian data, dan penarikan kesimpulan. Hasil dari penelitian ini menunjukkan bahwa setiap pasangan orang tua memiliki metode dan variasinya sendiri dalam menerapkan ajaran agama kepada anaknya, yaitu metode keteladanan, metode nasihat, metode pembiasaan, dan metode hukuman. Terdapat dua saran dalam penelitian ini yang ditujukan kepada orang tua agar anak dapat tumbuh dan berkembang secara optimal, pertama, pola asuh ayah dan ibu sebaiknya selaras; kedua, orang tua hendaknya menanamkan nilai Islam secara konsisten berdasarkan ajaran agama Islam.
\end{abstract}

Kata kunci: Nilai Agama Islam, Metode Penanaman Nilai Islam

Abstract - Method is a way or path that must be passed to achieve certain goals. How parents play their role can also be influenced by cultural factors. Parents will follow how education is applied by their culture.The method that was used in this study is qualitative research with descriptive. Data has been obtained from 6 parents and 3 children using interview and observation techniques. Then the data was analyzed using the Miles and Huberman methods which included data collection, data reduction, data presentation, and conclusion drawing. The results of this study has shown that, each couple have their own methods with different variation in applying religious teachings to their children, namely exemplary methods, methods of advice, methods of habituation, and methods of punishment. There are two suggestions in this study that intended to parents so that children can grow and develop optimally. First, father and mother should be parenting their children in harmony; second, the parents should be consistent in instilling the Islamic values based on Islam religion.

Keyword: Religious Values, Instilling Islamic Values 


\section{PENDAHULUAN}

$\mathrm{K}$ eluarga merupakan lembaga pendidikan yang pertama dalam kehidupan, yang eksistensinya sangat menentukan masa depan kehidup keluarga. Oleh karena itu, menentukan dalam proses pembinaan, pendidikan dan pembentukan kepribadian anak sejak dini, bahkan sejak masih dalam kandungan.

Menurut Miami (dalam Munir, 2010) "Orang tua adalah pria dan wanita yang terikat dalam perkawinan dan siap sedia untuk memikul tanggung jawab sebagai ayah dan ibu dari anakanak yang dilahirkannya". Islam telah menjelaskan mengenai peranan orang tua yang diatur dalam pelaksanaan kewajiban serta pemberian haknya kepada anak seperti, sejak dalam kandungan sampai menjelang dewasa memiliki hak perawatan dan pemeliharaan (alhadanah) yang wajib dilaksanakan oleh orang tuanya. Dalam Al-Quran seorang ayah atau suami dikatakan sebagai " $A r$ Rijaalul Qawwamun" artinya seorang pria (ayah/suami) merupakan pemimpin bagi keluarganya, yang sangat berperan dan berpengaruh bagi kemaslahatan anak dan istriistrinya. Terutama pada pendidikan anak, seorang ayah juga tidak kalah penting dari seorang ibu dalam mendidik anak-anaknya.Memberi tuntunan kepada suami bagaimana seharusnya bersikap dan berlaku dalam memberikan pembelajaran dan pendidikan terhadap istri yang pembangkang dalam membangun keluarga Islami QS an-Nisa ayat 34 .

Ibu sebagai sosok yang siap siaga dan serba bisa. Kasih sayang, kelembutan dan perhatiannya menempatkan ibu menjadi sosok yang dibutuhkan seluruh anggota keluarga (Yurita, 2009). Seorang ibu dikatakan ideal dalam Islam yaitu mampu mendidik anak dengan nilai ke Islaman sejak masih dini, memiliki budi pekerti yang baik (akhlakul karimah), selalu menjaga perilakunya agar menjadi teladan bagi anaknya, memiliki sikap penyabar, sopan serta lembut dalam berbicara agar kelak sang anak dapat memiliki kepribadian yang tangguh dalam ismai.
Allah berfirman dalam surat At-Tahrim: 6 yang artinya:

Hai orang-orang yang beriman, peliharalah dirimu dan keluargamu dari api neraka yang bahan bakarnya adalah manusia dan batu; penjaganya malaikat-malaikat yang kasar, keras, dan tidak mendurhakai Allah terhadap apa yang diperintahkan-Nya kepada mereka dan selalu mengerjakan apa yang diperintahkan.

Perintah ini ditujukan kepada keluarga. Namun, dalam hal ini sosok ibu yang menjadi prioritas utama dalam mendidik anak di dalam keluarga, karena anak yang diharapkan di dalam keluarga yaitu anak yang soleh dan solehah.

Terdapat 5 (lima) peran orang tua dalam pengembangan anak yaitu: (1) memelihara kesehatan fisik dan mental anak. Anak yang memiliki kesehatan mental yang baik akan memiliki beberapa karakter positif, misalnya dapat beradaptasi dengan keadaan, menghadapi stress, menjaga hubungan baik dan bangkit dari keadaan sulit. (2) meletakkan dasar kepribadian yang baik. Sejak usia dini orang tua harus menanamkan sikap yang baik kepada anak seperti, toleransi, berbagi, tolong menolong jika orang tua menanamkan sikap yang baik sejak usia dini sikap baik tersebut akan terbawa sampai anak dewasa. (3) membimbing dan memotivasi anak untuk mengembangkan diri. Orang tua yang pertama kali mendidik atau menanamkan pendidikan dasar kepada anakanaknya. Oleh karena itu hendaknya orang tua senantiasa memotivasi anak agar lebih giat dalam belajar dan meraih prestasi. (4) memberikan fasilitas yang memadai bagi pengembangan diri anak. Orang tua harus senantiasa menyediakan fasilitas yang baik dan memadai sesuai kebutuhan anak agar anak dapat berkembang dengan baik dan sesuai dengan keinginan orang tua dan (5) menciptakan suasana yang aman, nyaman dan kondusif bagi pengembangan anak. Keluarga adalah tempat untuk anak berlindung jika orang tua menciptakan suasana yang aman dan nyaman anak akan berkembang dengan baik sesuai keinginan orang tua (Iskandar, 2009). 
Bagaimana orang tua menjalankan peran juga dapat dipengaruhi oleh faktor budaya. Orang tua akan mengikuti bagaimana pengasuhan yang diterapkan oleh budayanya. Bangsa Arab suatu kelompok yang memiliki keunikan dalam mendidik anak, memiliki beberapa cara pengasuhan yang berbeda dibandingkan dengan masyarakat pada umumnya.Masyarkat Arab sangat mengutamakan ajaran agama Islam dalam mendidik anaknya. Di lingkungan Condet sudah cukup banyak dikelilingi dengan orang keturunan Arab. Para orang keturunan Arab di Condet ratarata sebagai pedagang yang berbaur dengan bangsa Indonesia, mereka sudah berbaur dengan wargawarga lain yang memang asli betawi. Di lingkungan ini masyarakat keturunan Arab masih banyak yang memegang teguh pendiriannya untuk tetap menikah dengan masyarakat Arab juga dan tidak sedikit pula yang memutuskan untuk menikah dengan orang-orang di sekelilingnya seperti orang betawi.Masyarakat Arab sudah cukup lama berada di kawasan Condet mungkin sekarang kawasan Condet sering disebut dengan istilah kampung Arab. Pada saat pasangan menikah menjadi suami istri maka dituntut untuk saling bekerja sama dalam membangun keluarga dan memikul tanggung jawab. Satu sama lain saling melengkapi dalam melaksanakan tugas.

Pengasuhan menurut Hastuti (2010) diartikan sebagai pengalaman, keterampilan, dan tanggung jawab sebagai orang tua dalam mendidik dan merawat anak. Cara orang tua mengasuh anak bisa dipengaruhi oleh lingkungan dimana orang tua tersebut tinggal karena lingkungan sangat berpengaruh.Bisa juga dipengaruhi oleh bagaimana dulu orang tua mendapatkan pengasuhan.

Cara orang tua mengasuh anak bisa dipengaruhi oleh lingkungan dimana orang tua tersebut tinggal karena lingkungan sangat berpengaruh. Bisa juga dipengaruhi oleh bagaimana dulu orang tua mendapatkan pengasuhan, orang tua biasanya mengikuti cara mengasuh dari bagaimana ia di asuh dulu. Jika pengasuhan anak belum dilakukan secara baik dan benar, kerap kali orang tua akan mendapatkan konflik dalam menjalankan pengasuhan.

Penanaman nilai-nilai keagamaan yang dilakukan sejak dini perlu dilakukan untuk membekali anak agar lebih matang menghadapi permasalahan kehidupan. Anak yang masih berada pada usia dini perlu ditanamkan nilai-nilai agama Islam sebagai pembentukan karakter, serta mengasah moral dan spiritual anak agar lebih peka terhadap segala bentuk Kebesaran Allah SWT yang telah ada disekelilingnya. Bentuk penanaman nilai-nilai agama Islam pada anak usia dini seperti meniru secara terbatas perilaku keagamaan yang dilihat dan didengarnya, meniru dan mengucapkan bacaan doa atau lagu-lagu keagamaan dan gerakan beribadah secara sederhana serta melakukan perilaku keagamaan secara berurutan dan mulai belajar membedakan perilaku baik dan buruk.

Nilai merupakan suatu hal yang melekat pada suatu hal yang lain yang menjadi bagian dari identitas sesuatu tersebut. Bentuk material dan abstrak di alam ini tidak bisa lepas dari nilai. Nilai memberikan definisi, identitas, dan indikasi dari setiap hal konkret ataupun abstrak. Nilai adalah suatu yang bersifat abstrak, ideal (Toha, 2000). Nilai bukan benda konkrit bukan fakta dan tidak hanya persoalan benar dan salah adalah yang menuntut pembuktian empirik, melainkan soal penghayatan yang dikehendaki, disenangi maupun tidak disenangi.

Lingkup perkembangan Nilai Agama dan Moral anak usia 4-5 Tahun, terdapat dalam Peraturan Mentri Pendidikan Nasional Nomor 137 Tahun 2014, meliputi kemampuan mengenal nilai agama yang dianut, mengerjakan ibadah, berperilaku jujur, penolong, sopan, hormat, sportif, menjaga kebersihan diri dan lingkungan, mengetahui hari besar agama, menghormati, dan toleran terhadap agama orang lain.

Secara umum pendidikan agama Islam bertujuan untuk meningkatkan keimanan, penghayatan, dan pengamalan tentang agama Islam, sehingga menjadi manusia muslim yang beriman dan bertaqwa kepada Allah SWT serta berakhlakul mulia dalam kehidupan pribadi, bermasyarakat, 
berbangsa dan bernegara (Muhaimin, 2008). Hidayat (2011) menuliskan tujuan khusus pendidikan nilai-nilai agama Islam pada anak usia dini adalah sebagai berikut:

1. Meletakkan dasar keimanan

2. Meletakkan dasar-dasar kepribadian/budi pekerti yang terpuji

3. Meletakkan kebiasaan beribadah sesuai dengan kemampuan anak.

Berdasarkan pengertian di atas dapat disimpulkan bahwa tujuan pendidikan nilai-nilai agama Islam yaitu memberikan bekal bagi anak berupa ajaranajaran Islam sebagai pedoman dalam hidupnya. Dengan harapan potensi yang dimilikinya dapat berkembang dan terbina dengan sempurna sehingga kelak anak akan memilki kualitas fondasi agama yang kokoh.

Metode adalah suatu cara atau jalan yang harus dilalui untuk mencapai tujuan tertentu (Maemunah, 2009). Metode berarti suatu cara kerja sistematik dan umum (Daradjat, dkk, 2011). Pendidikan menempati metode kedudukan terpenting setelah tujuan dari sederetan komponen-komponen pembelajaran. Tanpa adanya metode suatu materi pendidikan kurang berjalan secara sempurna. Demikian penting metode dalam proses pendidikan dan pengajaran, sehingga bisa dikatakan tidak berhasil proses belajar mengajar jika tidak menggunakan metode.

Macam-macam metode Pendidikan Agama Islam untuk mencapai tujuan dari pendidikan nilai-nilai agama Islam yang telah ditentukan, seorang guru dituntut agar cermat memilih dan menetapkan metode apa yang tepat digunakan untuk menyampaikan materi pelajaran pada peserta didik (Arief, 2002). Oleh karenanya, pendidik harus mempunyai kekreatifan dalam mendidik anak agar nantinya dalam menanamkan nilai-nilai agama Islam, mereka tidak merasa kesulitan dan nilainilai agama Islam dapat tertanam baik dalam benak anak.

Metode pendidikan nilai-nilai agama Islam merupakan cara yang digunakan oleh orang tua agar agama Islam dimengerti dan melekat dalam diri anak. Menurut Ulwan (2015), ada beberapa metode yang dapat digunakan dalam proses mendidik anak diantaranya yaitu:

1. Metode Keteladanan

Keteladanan dalam pendidikan adalah cara yang paling efektif dan berhasil dalam mempersiapkan anak dari segi akhlak, membentuk mental, dan sosialnya.Hal ini dikarenakan pendidik adalah panutan atau idola dalam pendangan anak dan contoh yang baik di mata mereka. Anak akan meniru baik akhlaknya, perkataannya, perbuatannya dan akan senantiasa tertanam dalam diri anak.

\section{Metode pembiasaan}

Telah ditetapkan dalam syariat Islam bahwa anak semenjak lahir sudah diciptakan dalam keadaan bertauhid yang murni, agama yang lurus dan iman kepada Allah.Dari sini, tibalah saatnya pembiasaan pendekatan, dan pendisiplinan mengambil perannya dalam pertumbuhan anak dan menguatkan tauhid yang murni, akhal yang mulia, jiwa yang agung, dan etika syariat yang lurus.

Pembiasaan ini dilakukan dengan jalan memberikan penjelasan-penjelasan seperlunya, perbuatan-perbuatan dan ucapan-ucapan dengan memperhatikan taraf kematangan anak.Di dalam mendidik anak pembiasaan sangat diperlukan. Apa lagi dalam menanamkan nilai-nilai agama Islam pada anak, semakin banyak diberikan latihanlatihan pembiasaan nilai keagamaan karena anak di usia ini masih suka meniru kegiatan-kegiatan yang dilakukan orang yang disekelilingnya baik perbuatan berupa kegiatan ibadah yang dilakukan oleh orang disekitarnya. Diharapkan dengan metode pembiasaan, maka anak akan berproses secara langsung dengan lingkungan dan pendidikan yang diajarkan.

\section{Metode Nasihat}

Merupakan metode yang efektif dalam membentuk keimanan anak, akhlak, mental dan sosialnya, hal ini dikarenakan nasihat memiliki pengaruh yang besar untuk membuat anak mengerti tentang hakikat sesuatu dan memberinya kesadaran tentang prinsip-prinsip Islam. Metode pendidikan dengan nasihat adalah memberikan nasihat yang baik kepada anak sehingga anak meniru dan 
melaksanakan apa yang dilakukan oleh pendidik dan orang tua.

Metode nasihat akan berjalan baik pada anak jika seseorang yang menasihati juga melaksanakan apa yang dinasihatkan, fungsi metode nasihat adalah untuk menunjukan kebaikan dan keburukan, kerana tidak semua orang bisa menangkap nilai kebaikan dan keburukan.

4. Metode Perhatian atau Pengawasan

Mengikuti perkembangan anak dan mengawasinya dalam pembentukan akidah, akhlak, mental, dan sosialnya. Begitu juga dengan terus mengecek keadaanya dalam pendidikan fisik dan intelektualnya.

Islam dengan prinsip-prinsip yang holistik dan abadi mendorong para orang tua dan pendidik lainnya untuk selalu memperhatikan dan mengawai anak-anak mereka disemua aspek kehidupan dan pendidikannya. Perhatian dan pengawasan pada diri pendiidkan merupakan asas pendidikan yang paling utama karena dengan cara seperti itu anak selalu berada dibawah pantauan pendidik, mulai dari gerak-geriknya, perkataan, perbuatan, sampai orientasi dan kecendrungannya.

\section{Metode Hukuman}

Hukuman-hukuman yang terdapat dalam syariat Islam mencakup prinsip-prinsip yang holistik yang mengandung perkara-perkara penting yang tidak mengkin manusia dapat hidup tanpanya. Para ulama ijtihad dan ushul fiqh merangkumnya ke dalam 5 perkara yang dinamakan adhdharuriyat alkhams (lima hal yang primer) Atau al-kulliyat alkhams, yaitu: menjaga agama, jiwa, kehormatan, akal, dan harta. Mereka mengatakan bahwa hokum dan prinsip yang terdapat di dalam Islam bertujuan untuk menjaga lima hal yang primer di atas.

Metode hukuman merupakan suatu cara yang dapat digunakan oleh orang tua dalam mendidik anak apabila penggunaan metode yang lain tidak mampu membuat anak berubah menjadi lebih baik. Dalam menghukum anak, tidak hanya menggunakan pukulan tetapi bisa menggunakan sesuatu yang bersifat mendidik.
Ada beberapa metode hukuman yang dapat diterapkan oleh orang tua yaitu:

1. Lemah lembut dan kasih sayang

2. Menjaga tabi'at yang salah dalam menggunakan hukuman

3. Dalam upaya pembenahan, hendaknya dilakukan secara bertahap dari yang paling ringan hingga yang paling berat

Rasulullah shallallahu 'alaihi wa sallam bersabda, "Perintahkanlah kepada anak-anakmu untuk (melaksanakan) shalat (lima waktu) sewaktu mereka berumur tujuh tahun, pukullah mereka karena (meninggalkan) shalat (lima waktu) jika mereka (telah) berumur sepuluh tahun, serta pisahkanlah tempat tidur mereka." Hadits ini menunjukkan bolehnya memukul anak untuk mendidik mereka jika mereka melakukan perbuatan yang melanggar syariat, jika anak tersebut telah mencapai usia yang memungkinkannya bisa menerima pukulan dan mengambil pelajaran darinya dan ini biasanya di usia sepuluh tahun. Namun syaratnya, pukulan tersebut tidak terlalu keras dan tidak pada wajah.

Orang tua dapat menggunakan beberapa metode di atas untuk menerapkan nilai-nilai Islam kepada anak usia dini. Agar kelak anak dapat menjadi peribadi yang soleh dan solehah sesuai dengan yang diinginkan oleh orang tua dan anak dapat menerapkan ajaran yang diajarkan agama Islam.

\section{METODE PENELITIAN}

Tempat penelitian dilakukan di komunitas Arab Jakarta. Penelitian ini dilakukan di tiga keluarga yang bertempat tinggal di Condet Jakarta Timur 2 keluarga dan 1 keluarga di Cibubur. Penelitian ini menggunakan metode kualitatif. Metode Kualitatif, karena jenis penelitian ini memusatkan pada deskripsi data yang berupa kalimat-kalimat yang memiliki arti mendalam yang berasal dari informan dan perilaku yang di amati. Data hasil penelitian ini berupa fakta-fakta yang ditemukan pada saat di lapangan oleh peneliti (Sugiyono, 2016). Pendekatan yang gunakan adalah pendekatan kualitatif deskriptif.

Subjek penelitian ini adalah 3 keluarga keturunan Arab yang berpindah ke Indonesia, terdiri dari 
ayah, ibu dan anak. Sumber data yang digunakan adalah data primer dan data skunder. Data primer dalam penelitian ini adalah 6 orang tua dan 3 anak, data skunder dalam penelitian ini melalui observasi kepada anak.

Teknik Pengumpulan Data yang digunakan adalah observasi dan wawancara.Observasi adalah teknik pengumpulan data dengan melakukan pengamatan langsung pada objek kajian, observasi dilakukan kepada anak.Wawancara yang dilakukan kepada 6 orang tua dan 3 anak.

Analisis data dalam penelitian ini menggunakan teknik analisis model alir. Langkah-langkah analisis data model alir menurut Miles dan Huberman (dalam Sugiono, 2012), 1. Pengumpulan Data, 2. Reduksi Data, 3. Penyajian Data/ Data Display, 4. Penarikan Kesimpulan

Peneliti dalam penelitian ini menggunakan triangulasi teknik yaitu, triangulasi teknik berarti peneliti menggunakan teknik pengumpulan data yang berbeda-beda untuk mendapatkan data dari sumber data yang sama. Peneliti menggunakan observasi partisipatif, wawancara mendalam, Serta dokumentasi untuk sumber data yang sama secara serempak.

\section{HASIL DAN PEMBAHASAN}

Ketiga keluarga subjek yang diteliti oleh peneliti mempunyai lingkungan yang berbeda satu dengan lainnya dua keluarga bertempat tinggal di kawasan Condet Jakarta Timur dan satu keluarga tinggal di kawasan Cibubur. Subjek pertama (MH) sudah memiliki rumah sendiri dikawasan Condet Jakarta Timur di dalam rumahnya hanya keluarga inti ayah, ibu, 2 anak, dan asisten rumah tangga. Subjek kedua (FN) bertempat tinggal di kawasan Condet Jakarta Timur dan hidup bersama kedua orangtua dari pihak ayah serta saudara dari pihak ayah, dan asisten rumah tangga.Subjek ketiga (KA) tinggal dikawasan Cibubur di rumah mereka sendiri tanpa kehadiran anggota keluarga lainnya.

\section{Subjek penelitian 1}

Subjek pertama bernama $\mathrm{MH}$ berjenis kelamin laki-laki. MH merupakan anak pertama dari pasangan Bapak AL dan Ibu AS, MH memiliki adik perempuan bernama $\mathrm{FH}$ yang usianya tidak jauh berbeda. Bapak AL bekerja sebagai pegawai BUMN di daerah TB Simatupang dan memiliki latar belakang pendidikan S1, sedangkan Ibu AS sebagai ibu rumah tangga yang kesehariannya mengurus $\mathrm{MH}$ dan FH dan memiliki latar belakang pendidikan S1.

Bapak AL dan Ibu AS sudah menikah selama 6 tahun.Kedua orang tua MH lahir di Jakarta. Usia Bapak AL saat ini adalah 31 tahun dan Ibu AS memasuki usia 27 tahun. Pertama kali Bapak AL dan Ibu AS dipertemukan oleh kedua orang tua, setelah beberapa bulan berkenalan keduanya memutuskan untuk kejenjang yang lebih serius. Pada awal tahun 2012 orang tua MH memutuskan untuk menikah.Selang beberapa bulan setelah menikah Ibu AS mengandung $\mathrm{MH}$ dan $\mathrm{MH}$ lahir pada tahun 2013 awal.

Orang tua MH menikah pada tahun 2012 di Jakarta. Selang beberapa bulan pernikahan ibu MH mengandung $\mathrm{MH}$ dan $\mathrm{MH}$ lahir pada awal tahun 2013. Sekarang MH memasuki usia 5 tahun. Ibu MH ini merupakan anak pertama dalam keluarganya sedangkan Ayah MH merupakan anak kedua dalam keluarganya.Pendidikan terakhir ibu dan ayah $\mathrm{MH}$ adalah S1. Ayah $\mathrm{MH}$ bekerja sabagai pegawai BUMN, ibu MH sebagai ibu rumah tangga.MH memiliki adik bernama $\mathrm{FH}$ yang usianya 3 tahun. Ayah MH bekerja pada hari Senin-Jumat dari pukul 06.00 WIB sampai pukul 17.00. MH bersekolah di sekolah Islam yang tidak jauh dari rumah, setiap harinya $\mathrm{MH}$ diantar oleh ibunya ke sekolah sedangkan adiknya dititip dirumah neneknya bersama dengan asisten rumah tangga.Kediaman nenek MH tidak begitu jauh dari rumah $\mathrm{MH}$.Biasanya sambil menunggu $\mathrm{MH}$ pulang sekolah ibu MH mengurus restorannya yang juga tidak begitu jauh dari sekolah $\mathrm{MH}$.

MH bersekolah tidak jauh dari rumahnya biasanya MH diantar ke sekolah oleh ibu AS. Ibu AS terkadang menunggu $\mathrm{MH}$ di sekitar sekolah kadang juga ibu AS pergi kerestoran milik 
keluarganya yang tidak begitu jauh dari sekolah MH.Ketika MH berangkat sekolah adik MH dibawa oleh asisten rumah tangga ke rumah neneknya yang juga tidak begitu jauh dari rumah MH.

Setelah pulang sekolah MH biasanya menjemput adiknya dirumah neneknya dan setelah itu kembali kerumah.Setelah sampai kerumah MH berganti pakaian dan biasanya bermain dikamar bermainnya bersama $\mathrm{FH}$ dan asisten rumah tangga. Ketika Bapak AL pulang MH biasanya bermain bersama Bapak AL. Ketika maghrib keluarga MH biasanya solat berjamaah, setelah selesai solat $\mathrm{MH}$ dan FH mengaji bersama atau membaca Iqra.

\section{Subjek penelitian 2}

Subjek kedua bernama FN berjenis kelamin perempuan. FN merupakan anak tunggal dari pasangan Bapak MZ dan Ibu SS. Bapak MZ bekerja sebagai wirausaha di daerah Jakarta Timur dan memiliki latar belakang pendidikan S1, sedangkan Ibu SS sebagai ibu rumah tangga yang kesehariannya mengurus FN dan memiliki latar belakang pendidikan S1.

Bapak MZ dan Ibu SS sudah menikah selama hampir 5 tahun. Ibu SS lahir di Jakarta ketika umur Ibu SS memasuki 6 tahun keluarganya pindah ke Arab sedangkan Bapak MZ lahir di Ternate dan pindah ke Arab saat usianya 11 tahun, kedua orang tua FN besar di Arab. Bapak MZ dan Ibu SS pindah ke Jakarta ketika umur keduanya memasuki usia 20 tahunan.

Sekarang usia Ibu SS memasui usia 31 tahun sedangkan Bapak MZ memasuki usia 33 tahun. Tak lama ketika pindah ke Jakarta kedua orang tua FN dipertemukan oleh kedua orang tua mereka . Beberapa lama setelah berkenalan Bapak MZ dan Ibu SS memutuskan untuk menikah pada akhir tahun 2013.Selang beberapa lama setelah menikah Ibu SS mengandung FN dan lahir pada tahun 2014 akhir. Orang tua FN menikah pada tahun 2013 di Jakarta. Selang beberapa bulan pernikahan ibu FN mengandung FN dan FN lahir pada akhir tahun 2014. Sekarang FN memasuki usia tahun ke-3. Ibu dan ayah FN sama-sama anak ke dua dalam keluarganya. Pendidikan terakhir ibu dan ayah FN adalah S1. Ayah FN bekerja sebagai wirausaha di daerah Jakarta Timur, ibu FN sebagai ibu rumah tangga. FN merupakan anak tunggal Ayah FN bekerja hari Senin-Sabtu.

FN belum bersekolah tetapi Ibu SS ingin memasukan FN ketempat mengaji didekat rumahnya. Ibu SS ingin FN belajar mengaji terlebih dahulu. Setiap harinya FN bermain dirumah bersama ibunya. Setiap saat waktu solat orang tua FN mengajak FN solat berasma tapi sering kali FN menolak untuk ikut solat bersama, ketika di minta untuk membaca Iqra FN sangat bersemangat dan membaca dibantu oleh ibu SS.

\section{Subjek penelitian 3}

Subjek ketiga bernama KA berjenis kelamin perempuan. KA merupakan anak pertama dari pasangan Bapak AA dan Ibu C, KA memilki adik perempuan bernama AA yang usianya tidak jauh berbeda. Bapak AA bekerja sebagai pegawai swasta di daerah Cibubur dan memiliki latar belakang pendidikan S1, sedangkan Ibu C sebagai Ibu rumah tangga yang kesehariannya mengurus KA dan AA dan memiliki latar belakang pendidikan S1.

Bapak AA dan Ibu C sudah menikah selama 6 tahun.Kedua orang tua KA lahir di Arab. Sekarang usia Bapak AL memasuki usia 36 tahun dan Ibu C memasuki usia 27 tahun. Bapak AA dan Ibu C dipertemukan oleh kedua orang tuanya dan langsung memutuskan untuk menikah pada tahun 2012.Selang beberapa bulan menikah Ibu C mengandung KA dan lahir pada tahun 2013 awal.

Sebelum pindah ke Jakarta KA sudah diajakrkan agama karna orang tuanya merasa agama lebih penting dari apapun, KA diajarkan agama oleh ibu C karna Ibu C selalu dirumah bersama KA. Ketika pindah ke Jakarta orang tua KA langsung memasukan KA ke tempat mengaji yang tidak begitu jauh dari rumahnya.KA belajar mengaji setiap hari pelajaran mengaji dimulai setelah solat asar. Setelah pulang KA biasanya solat bersama orang tua dan adiknya, setelah solat KA biasanya menghafal doa sehari-hari dan bacaan solat. 
Orang tua KA menikah pada tahun 2012 di Arab. Keluarga KA baru beberapa bulan tinggal dijakarta.KA sekarang berusia 5 tahun. Pendidikan terakhir ibu KA dan ayah KA adalah S1. Ayah KA bekerja dikantor swasta di daerah Cibubur, ibu KA sebagai ibu rumah tangga. KA memiliki satu orang adik bernama AA . Ayah KA bekerja hari SeninJumat dari pukul 07.00 sampai dengan 16.00. KA belajar mengaji di masjid dekat rumahnya, orang tua KA ingin KA belajar agama terlebih dahulu sebelum masuk sekolah.KA biasanya belajar mengaji diantar oleh asisten rumah tangga.KA belajar mengaji setiap hari dari pukul 16.00 sampai pukul 17.00.

Dua (2) subjek penelitian yaitu FN dan KA merupakan anak yang belum masuk TK dan 1 subjek penelitian yaitu MH sudah memasuki TK. MH anak yang cukup pintar di rumah ibu AS sering mengajak $\mathrm{MH}$ untuk mengulang pelajaran yang diajarkan disekolah. FN dan KA sama-sama belum memasuki TK tapi kedua ibu mereka sangat giat dalam mengajarkan anaknya, FN dan KA terlihat seperti anak yang sudah masuk TK mereka mengetahui semua warna, hafal angka, mereka juga sudah tau tentang huruf vokal. Walaupun tidak bersekolah orang tua FN dan KA mengajarkan anak-anak mereka yang diajarkan di sekolah.

Menamankan nilai Islam sangat penting terumata saat anak masih menginjak usia dini. Anak diajarkan agama Islam sejak anak-anak agar tetap melekat dihati dan saat anak usia dini diajarkan tentang agama Islam ia akan cepat menangkap dan cepat mengerti, banyak metode yang dapat digunakan oleh orang tua dalam menanamkan nilai Islam pada anak. Menurut Ulwan (2015) ada 5 metode yang dapat digunakan dalam proses mendidik anak motode keteladanan, metode pembiasaan, metode nasihat, metode perhatian dan pengawasan, metode hukuman.

Penanamankan nilai agama Islam di keluarga $\mathrm{MH}$ bapak AL yang lebih berperan dari pada ibu AS. Bapak AL lebih munggunakan metode keteladanan bapak AL selalu menjadi contoh untuk MH dan adiknya.Bapak AL juga selalu mencontohkan beribadah mengaji dengan rutin dan selalu menolong orang agar anak tidak hanya di berikan nasihat tentang beribadah tapi bapak AL ingin menjadi panutan yang baik untuk anak-anaknya. Sedangkan ibu AS lebih condong kepada metode hukuman jika anak nya tidak mau maka ibu AS akan memarahi anaknya dan anak nya tidak diperbolehkan bermain.

Penamankan nilai agama Islam di keluarga $\mathrm{FN}$ ibu SS yang lebih berperan dari pada bapak MZ. Ibu SS lebih menggunakan metode keteladanan Ibu SS selalu memberikan FN contoh yang baik dalam beribadah ibu SS juga selalu mengajak FN solat bersama mengaji bersama dan melakukan hal positif bersama. Bapak MZ lebih menggunakan metode nasihat jika FN tidak ingin beribadah bersama bapak MZ akan menasihati FN dengan lembut walalupun kadang FN tetap tidak mau diajak beribadah bersama.

Penanamankan nilai agama Islam di keluarga KA bapak AA lah yang lebih berperan dari pada ibu C. Bapak AA lebih munggunakan metode kebiasaan walaupun bapak AA jarang berada dirumah tetapi bapak AA selalu mengingatkan anaknya tentang solat 5 waktu dan selalu membiasakan anaknya untuk membaca surat Yasin setelah solat maghrib. Sedangkan ibu $\mathrm{C}$ menggunakan metode nasihat jika anak tidak bisa diberi nasihat ibu $\mathrm{C}$ akan membawa nama bapak AA jika bapak AA tidak ada, agar anak-anak nya mau menurut dan melaksanakan kebiasaan dengan bapak AA.

\section{SIMPULAN DAN SARAN}

Ketiga keluarga mempunyai masing-masing metode yang di terapkan untuk menanamkan nilai agama Islam pada anak mereka bapak AL lebih menggunakan metode keteladanan sama seperti ibu SS, ibu ASlebih menggunakan metode hukuman, bapak MZ dan ibu $\mathrm{C}$ lebih menggunakan metode nasihat dan bapak AA lebih menggunakan metode kebiasaan.

Ketiga keluarga sudah sangat baik dalam mendidik agama sejak dini dengan menggunakan macammacam cara yang berbeda dan dengan cara yang cukup efektif. Mereka menjadikan solat, mengaji 
menjadi kebiasaan untuk dilakukan sehari-hari. Orang tua KA dan orang tua FN lebih memilih memasukan anak mereka ke TPA untuk belajar mengaji terlebih dahulu sedang kan orang tua $\mathrm{MH}$ memilih memasukan anak nya ke sekolah yang berbasis islam agar anak nya tetap berada dilingkungan yang baik.

Saran berdasarkan penelitian ini ditujukan kepada orang tua agar anak dapat tumbuh dan berkembang secara optimal, yaitu: pertama, Pola asuh ayah dan ibu sebaiknya selaras; kedua, kedua orang tua menanamkan nilai Islam secara konsisten berdasarkan ajaran agama Islam, misalnya ayah menjadi imam ketika solat berjamaah.

\section{DAFTAR PUSTAKA}

Arief, A. (2002). Pengantar ilmu dan metodologi pendidikan Islam. Jakarta: Ciputat Pers.

Thoha, C. (2000). Kapita selekta pendidikan Islam. Yogyakarta: Pustaka Pelajar.

Daradjat, Z., dkk. (2000). Ilmu pendidikan Islam. Jakarta: Bumi Aksara.

Hamalik, O. (2007). Manajemen pengembangan kurikulum. Bandung: PT. Remaja Rosdakarya.

Yurita, Lidia. (2009). Mukjizat Doa Ibu!. Yogjakarta: Diva Press.
Munir, Z. (2010). Pengertian orang tua. Bandung. PT Refika Aditama.

Muhaimin, dkk. (2008), Pengembangan model kurikulum tingkat satuan pendidikan (KTSP) pada Sekolah dan Madrasah. Jakarta: PT Raja Grafin.

Peraturan Menteri Pendidikan dan Kebudayaan Republik Indonesia Nomor 137 Tahun 2014 tentang standar pendidikan anak usia dini.

Soekanto, S. (2002). Teori peranan. Jakarta: Bumi Aksara.

Sugiyono. (2016). Metode penelitian pendidikan (pendekatan kuantitatif, kualitatif dan $R \& D$ ). Penerbit CV. Alfabeta: Bandung.

Ulwan, A.N. (2012). Pendidikan anak dalam islam. Solo: Insan Kamil. Jakarta: Bulan Bintang. (2005). Ilmu jiwa agama.

\section{(2011). Metode} pengembangan moral dan nilai-nilai agama. Jakarta: Universitas Terbuka. 